College of William \& Mary Law School William \& Mary Law School Scholarship Repository

1991

\title{
Freedom of Speech and the Flag Anti-Desecration Amendment: Antinomies of Constitutional Choice
}

William W. Van Alstyne

William \& Mary Law School

\section{Repository Citation}

Van Alstyne, William W., "Freedom of Speech and the Flag Anti-Desecration Amendment: Antinomies of Constitutional Choice" (1991). Faculty Publications. 1622.

https://scholarship.law.wm.edu/facpubs/1622

Copyright c 1991 by the authors. This article is brought to you by the William \& Mary Law School Scholarship Repository. https://scholarship.law.wm.edu/facpubs 


\title{
Freedom of Speech and the Flag Anti-Desecration Amendment: Antinomies of Constitutional Choice
}

\author{
William W. Van Alstyne
}

\section{Introduction}

On June 21, 1989, in Texas v. Johnson, the Supreme Court held that the First Amendment does not permit imprisonment for burning a flag in the course of an open political demonstration. 'The Court's decision was widely featured on all major television networks the same day it came down, replaying film footage of the original incident as it had occurred in front of the Dallas City Hall. The Supreme Court decision came within three weeks of the shooting of students for demonstrating in Tiananmen Square in Beijing, events also replayed on television sets here at home. It was a summer unusually full of tumultuous events, even as one-party Communist regimes continued to come apart in eastern Europe and totalitarianism elsewhere continued to crack and break up.

In response to the Court's decision in Texas v. Johnson, however, President Bush did not speak to the contrast of these events. Rather, speaking from a flag-rimmed rostrum constructed for the occasion in front of the famous lwo Jima flag memorial in Washington, the President called on Congress to protect the flag. He did not contrast the freedom of political demonstration the Court had affirmed with the shootings and jailings even then still ongoing in the People's Republic. Instead, he proposed the following amendment to the Constitution of the United States for prompt passage by two-thirds of both Houses in Congress and for prompt ratification by the states: "The Congress and the States Shall Have Power to Prohibit the Physical Desecration of The Flag of the United States."

The amendment was at once introduced in Congress where, however, it became temporarily sidetracked when Democratic majorities in both houses rushed to propose a new "Flag Protection Act," rather than the proposed amendment. At the time, it was clear they were not eager to approve an amendment, but by offering a new act - to do by redrafted statute what the President proposed to do by amendment - they hoped to avoid any political blame for being less patriotic than president Bush and the Republicans. ${ }^{2}$ In turn, the President allowed the new act to become law without his signature, even while indicating that he believed it to be an insufficient substitute for the proposed amendment he continued to support as the appropriate response.

The new act of Congress was swiftly tested by political demonstrators in Washington, D.C., and in Seattle, Washington. The two Federal district courts quickly vindicated the

This essay is adapted from Notes submitted in opposition to the proposed 27 th Amendment- the anti-flag desecration amendment-when it was under consideration in the House and Senate in 1989 and 1990 . 
President's view. Each held that the cosmetic difference between the redrafted Federal statute and the original Texas statute struck down in Texas v. Johnson was of insufficient constitutional significance to make a difference under the First Amendment. ${ }^{3}$ Each, therefore, on facts similar to those in Texas $v$. Johnson, held the new Federal act unconstitutional as applied. On June 11,1990, on further and final review of these two new cases under the revised Federal statute, the Supreme Court agreed. ${ }^{4}$

The proposed 27th Amendment was at once re-introduced in Congress. After a flurry of debate in the House, it was approved by a clear majority but not by the extraordinary two thirds required by Article V of the Constitution. As it failed to carry the House, the debate in the Senate collapsed. It carried the President's strong support to the end, however, and at least one national poll indicated that a substantial number of Americans clearly felt it to be a good measure for the country to enact.

What did the proposed 27 th Amendment to the Constitution mean? How would it have worked? What kind of flag uses would it have covered? What kind of legislation would it have insulated from review under the First and Fourteenth Amendments? What impact on our understanding of free speech might it have had? And what would it have meant, if anything, in other countries where freedom of political dissent remains under attack? These are some of the questions one should want to think about before adding a provision to the Constitution of the kind the President proposed. It is entirely proper to take their measure even now, moreover, though the momentum for the amendment has passed away. For it is in reflecting on these things that we may better understand the meaning of freedom of speech under our First Amendment today. A review of the amendment is also worthwhile because it will help one come to terms with the original decision in Texas $v$. Johnson. It may help one sort out what made Texas $v$. Johnson a welcome and truly important case.

There were, broadly speaking, two kinds of issues raised by the proposed amendment. First, there was the question of the amendment's scope in terms of the kind of legislation it would authorize. Just what would it have empowered Congress and the states to do? Second, there was also the question of the extent to which the amendment would affect the First Amendment as interpreted and applied by the Supreme Court. How much of that amendment, if any, would the proposed amendment have set aside?

After exposing this hitherto unexplored feature of the amendment in Part I, I shall suggest in Part II of this brief review why the amendment would have been a source of uncertainty regarding the kinds of legislation it would and would not sustain, and what a profound mistake its adoption as part of our constitution would have been. In proceeding in this fashion, I hope we may also see how events associated with this amendment and with Texas $v$. Johnson also bear on events in other places such as those in Tiananmen Square.

\section{Did the Proposed 27th Amendment Purport to Alter or Affect Any Interpretation of the First Amendment?}

It is a seemingly odd thing that, although the amendment was introduced to overcome a decision of the Supreme Court based squarely on the First Amendment, the proposed amendment left the First Amendment intact and said nothing to suggest that the First Amendment was to be deemed inapplicable to any legislation adopted pursuant to its own provisions. In this singular aspect, moreover, the proposed amendment was wholly unlike past amendments that had been proposed and ratified to overcome other controversial 
decisions by the Supreme Court. ${ }^{5}$ Indeed, nothing on the face of the proposed amendment actually purported to mandate a different outcome in a case like Texas v. Johnson, as one may see from reviewing the actual case itself.

In Texas v. Johnson, ${ }^{6}$ the Texas State Court of Appeals did not reverse Gregory Johnson's conviction on the basis that the State of Texas lacked some general power to forbid the desecration of venerated objects - the crime for which Gregory Johnson was convicted. Rather, it reversed his conviction solely on the basis of the First Amendment where the facts of the case placed Johnson's particular conduct within the protection of the First Amendment as part of an open, public political demonstration and where his acts were protected as a recognized form of free speech. Concretely, this is what the Texas Court of Criminal Appeals held: " "We hold that section 42.09(a)(3) [the state flag antidesecration act] may not be used to punish acts of flag desecration when such conduct falls within the protection of the First Amendment. We express no view as to whether the State may prosecute acts of flag desecration which do not constitute speech under the First Amendment." ${ }^{\circ 8}$ So the state court itself distinguished acts of demonstrative flag use in a political setting from unprotected acts of vandalism, theft, or defilement (e.g., throwing paint on a flag being carried by another), in drawing its own clear First Amendment lines. And the Supreme Court affirmed just that decision, as it likewise decided the two later cases, under the redrafted congressional statute, on the same First Amendment grounds.

In order to forestall a decision like that reached solely on First Amendment grounds by both the state court and the Supreme Court in Texas v. Johnson, moreover, one might suppose that an amendment seeking that effect would need to read something much more like this: "The First Amendment shall not be deemed applicable to Federal or state legislation prohibiting the physical desecration of any American flag." But the proposed amendment did not say anything like this. Nor did it propose anything like the following terms: "Neither the First nor the Fourteenth Amendment shall be construed to forbid the conviction of any person who physically desecrates any flag of the United States." Far from saying anything that suggests the First Amendment should be deemed inapplicable to any state or national law providing penalties for what the government may regard as the physical desecration of some facsimile of the flag (whether or not the government's property and whether or not used in protest of or dissent from some policy of the United States), however, the amendment simply tracked the form of other clauses vesting certain ordinary affirmative powers in Congress. It tracked the form of such routine constitutional provisions, that is, as these:

The Congress shall have power to regulate Commerce with foreign Nations, and among the several states, and with the Indian tribes ${ }^{9}$

The Congress shall have Power to establish Post Offices and post Roads ${ }^{10}$

Indeed, the comparison with other clauses of this sort is so striking that the proposed amendment should be examined again, virtually side by side: "The Congress and the States Shall have Power to Prohibit the Physical Desecration of The Flag of The United States."

But we know, of course, that the First Amendment fully applies to any act adopted by Congress pursuant to any of its previously enumerated express powers, whether it is an act regulating commerce among the several states or an act establishing post offices and post roads. " And we know, too, that the proposed amendment stated no exception in respect to any law adopted pursuant to the particular power ("to prohibit the physical 
desecration of the flag") to which it speaks. If, then, though an action of the sort that Johnson participated in were subsequently to be prosecuted pursuant to some state or national law based on this amendment, ${ }^{12}$ if the act were also an act within the First Amendment in light of the circumstances involved in the particular case (like those involved in Johnson itself $f^{13}$ ), when called upon to show why no First Amendment claim should be heard, what can one point to in the proposed amendment to make good any such claim?

The origin of the proposed amendment doubtless did lie in the felt dissatisfaction of those who sponsored it with the manner in which the Supreme Court had construed and applied the First Amendment. But to have their way in this matter, if they did mean to oust the First Amendment from further consideration in this matter, it was incumbent upon them to say so. An amendment that would do so is quite different from the amendment that was introduced and endorsed by President Bush. It is different, moreover, because on its face it would declare that this nation does not want or does not deem the First Amendment to be appropriate to one particular kind of symbolic expression despite its own Supreme Court's view that the First Amendment does apply to such conduct and that it applies unexceptionably. It is also different in the important sense that the very process of confronting the issue in those terms would have made the debate in Congress and elsewhere very different. When put that way, I think it much less likely that any amendment, so proposed and so understood, would have rallied much support. The events from Tiananmen Square would have been drawn on powerfully to show the blow any such amendment would deliver against our own Constitution. It would never have gotten off the ground.

Suffice it to say, however, that this amendment did not do so. Indeed, it addressed none of these matters at all. And why not? Because, no doubt, it would have been seen even more clearly for what it was and would itself doubtless have led to the amendment's defeat. We know that any such amendment would, in all likelihood, not pass. Such an amendment would, thus framed, in all likelihood not, in fact, be approved by many who otherwise may not approve every Supreme Court decision but who nonetheless would not want so to amend the Constitution of the United States.

Behind Texas $v$. Johnson, there lay a significant history. Over the years, the Supreme Court had reviewed more than a half-dozen criminal convictions involving flag use, and the results were not all of a piece. On the one hand, the Court has found little difficulty sustaining regulations restricting the commercialization of flags or flag facsimiles as an incident of hawking goods or promoting commercials ales. ${ }^{14}$ On the other hand, like many ordinary citizens in this country, the Court had experienced genuine problems in sorting out other events involving flag uses in keeping faith with the First Amendment, in noncommercial settings. And, overall, it had drawn significant, useful First Amendment lines strongly protecting rights of political dissent. For example, an individual who, believing a national policy to be wrong and unworthy of the United States, may signal his or her message even in the manner of an international distress signal, i.e., by flying the flag on his car antenna or in his own front window, upside down. Another may emboss it with taped superimposition of a peace sign. ${ }^{15}$ Generally, both kinds of acts would be regarded as forms of political expression clearly protected by the First Amendment to our Bill of Rights, not just under the Court's decision in Texas v. Johnson, but also because they were already so regarded by the Court prior to that decision.

A case may instead involve a black citizen and war veteran, grief-stricken by the news account he receives by radio of the purported shooting in the South of a civil rights figure. 
Weeping, he takes his own flag to the street beside his apartment. Cradling it, he burns it in despair. ${ }^{16}$ Is this a crime? Shall it be constituted a crime? Does one see no First Amendment issue at stake? A very large number of Americans certainly might, even as the Supreme Court did.

So the proposed amendment rather willfully said nothing of these matters. It spoke no word as to how the Supreme court should construe and apply the First Amendment in cases involving acts of flag "desecration:" where - as is typically the case-the flag is not government property but may be a personal facsimile made of paper or other material and is used in some demonstrative way to express dissent from some policy or position of the government of the United States. Indeed, on its face, the proposed amendment affected no previous application of the First Amendment in any way at all. Insofar as it meant nonetheless to do so, it hid that purpose (to such extent that it harbored that purpose) underneath calculated language. It hoped, thereby, to slide easily into place.

If the proposed amendment did mean to exempt from First Amendment review all such legislation as would fit within the power vested in Congress and the states, then, of course, one would want to have a very clear picture of that power because, by hypothesis, the First Amendment would be cut off from any act otherwise bearing on things one may do in respect to the flag. ${ }^{17}$ So, just what would the amendment, thus understood, have done?

\section{The Unravelling of an Ill-Considered Amendment}

The choice of language restricting the amendment to allow punishment only of acts of "physical" desecration was deliberate. At one stage, before it became somewhat unravelled (as we shall see), it was meant to represent some serious concession to First Amendment concerns - to keep the amendment itself within reasonable bounds. It initially reflected an intention to reach only forms of actual physical disfigurement of a flag, whether by mutilation, burning, tearing, spitting on a flag, or some other physical besmirching of it in some other way. It expressly did not mean to reach mere words of contempt or verbal expressions of derision about the flag or about anything which, in the opinion of the offending speaker, the flag allegedly represents. So much as this seemed quite clear. In short, as long as the flag (no matter whose flag) is not itself physically desecrated, i.e., as long as it is intact, unaltered, unmutilated, unburnt, physically unsullied, the amendment is still in its sheath. Certainly an ordinary citizen's posting of a flag, on a standard angled from his own porch in the usual way, was not meant to be affected by any legislation possibly based on this amendment.

But likewise, then, assuredly the amendment would not reach the flying of any intact flag, even giant size, say, from a flagpole outside a Hardee's Fast Food Restaurant? Possibly, but somehow the example becomes contentious insofar as some might regard this to be an inappropriate (because commercial) use, even one in their view that is physically desecrative because it seeks to identify the commercial product of the entrepreneur with the national flag. Still, in keeping with the emphasis solely on "physical" desecration, perhaps there is no reaching such a use by legislation connected with this amendment. The flag's use may be objectionable to some, even conceivably mildly "desecrative" in some sense, but "physically" desecrative, perhaps not.

But if that much is so, then similarly the amendment ought to be equally inapplicable as addressed to an American Nazi Party march, otherwise protected by the First Amendment, a parade involving the carrying of a sound, unaltered, intact American flag at the 
head of the march. It i.e., this use likewise involves no mutilation, no alteration, no burning. spitting on, rending, etc. of the standard itself. There is no more "physical" desecration of the flag here, any more than in the presupposed Hardee's Restaurant case.

What, then, however, of another who is not a Nazi and who does not engage the use of the flag as part of a political assembly or parade, but who merely displays the flag upside down, e.g., as a member of a group protesting some U.S. military engagement abroad they believe to be an undeclared war and an immoral use of force? Is there any physical desecration in this act? Evidently, some think there may be, and, indeed, those purporting to speak for the administration in support of the amendment testified that, in their view, the amendment would sustain legislation of exactly this prohibitory kind ${ }^{18}$ But if one is inclined to stretch the word "physically" to include the mere manner of displaying an intact flag (e.g. displaying it upside down as a physically desecrating manner of display) on the reasoning that such a manner of display is inappropriate and disrespectful of appropriate flag display, one needs to reconsider all the cases previously posed. If the amendment can be stretched in this way, many may equally well conclude that for an American Nazi Party to parade with the flag at all is equally to "desecrate" the flag because of the infamous auspices of those who would so parade with it publicly. May Congress and state legislatures therefore also confine use of the flag to certain political parties in the United States? If it were to do so, e.g., to disallow the flag to be displayed under political auspices other than by the Republican, Democratic, and other "mainstream" parties, would such a law be (a) valid by force of this proposed amendment, or would it instead be (b) invalid either under the First Amendment or invalid (c) under the Fifth Amendment's implied equal protection clause (e.g., Socialists, Environmentalists, Communists, Libertarians)?

Next, then, to the different case of another who earefully affixes removable tape in the shape of a peace symbol and displays the flag in his home front window, albeit quite properly and respectfully, i.e., right side up? ? $^{14}$ Is this an act of "desecration" at all? To be sure, the flag thus displayed has a superimposed figure temporarily affixed; yet, the flag itself is not mutilated, burned, rent, dirtied, or soiled. In what respect, then, may it fairly be said that this is an act of "physical desecration" of the flag?"20

There is, moreover, a related problem of interpretation raised by the proposed amendment. The related problem is that of proposing and understanding some baseline definition of the phrase "the flag of the United States." Assuming one gets control of what it is to commit an act of "physical desecration," still, consistent with the proposed terms of the amendment, it is not subject to prohibition unless it is physical desecration of "the flag of the United States;" i.e., it must be such a flag for the amendment to apply at all.

Initially, to be sure, the term seems perfectly clear. One starts with a standard flag of the United States, then one does something with it or to it that "physically desecrates" that flag. And that understanding dovetails with the background from which this proposed amendment arose, i.e., Texas v. Johnson, involving, as it did, the burning of and spitting on a flag.

But suppose one does not start with a flag which one "physically desecrates." Rather, suppose one starts with a mere idea, e.g., a stars-and-stripes motif. The simplest example, perhaps, would be proposed by a swim suit designer who designs a bikini using the starsand-stripes motif. Raquel Welch has been previously photographed in just this way. In this instance, unlike Texas v. Johnson, there never was "a flag" that is altered, disfigured, torn, or modified. There was no flag "physically desecrated" in the construction of this 
suit. Neither did Ms. Welch physically desecrate any flag of the United States. Accordingly, may we suppose that laws adopted pursuant to the amendment would not apply to a case of this sort?

But if that is so in Ms. Welch's case, what, then, of any other original constructions that never were a flag, whether a flag bought commercially or a flag made at home? Will a law adopted pursuant to this amendment apply - or not apply - to a sculptor who, wishing to make a political point, constructs displays an original work that never was a flag of the United States, i.e., neither the sculptor's own "flag" or anyone else's? What he or she makes is nonetheless very "flaglike" and highly offensive in a number of respects. It has a projecting part in the shape of a swollen phallus, closely spiraled with alternate red and white stripes. The grotesque red-and-white striped barrel of this cannon sculpture rests on a gun carriage shaped to suggest a misshapen, oversized scrotum, painted blue, superimposed with white stars. The message of this work is loud, clear, and confrontational. Many may think it a physical desecration of the flag of the United States. But what "flag" was physically desecrated, since the artist never used a flag as such at all? ${ }^{21}$ How does one want to conclude in this case? That the artist can be sent to prison because his or he work violates a law duly enacted by Congress or some state, deemed authorized by the proposed amendment, or that the display of the work is, instead, fully protected by the First Amendment?

And if we but continue this new turn of emphasis, i.e., from the express requirement of some kind of physical sullying or physical changing (mutilation, burning, etc.) of a flag, to the emphasis on the additional idea of "desecration," how much further along do we get? Consider again the case of the person who, grief-stricken with the news of the reported assassination of a civil rights figure, weeps over his flag and cradles it in his arms, even while burning it on the sidewalk beside the tenement where he lives. What does one say? $?^{22}$ Is this an act of "flag desecration" or is it a cry of despair? Does the regret, the anguish, the whole posture of the person provide an insight and also a new First Amendment perspective we had not properly stopped to consider? Yet, here we have put an instance of an actual flag burning, no less! Yet again, the question of First Amendment freedom presses heavily in upon us from the outside as we come to terms with this case. Would legislation applied by some state to this case be deemed exempt from First Amendment review if the proposed amendment is adopted? But assuming that it might be, just why would we desire that this be so?

In the end, of course, it is ultimately this kind of question that must be asked more generally by Congress, whether in the case last put or in any other case. It is, in fact, just this very question we have actually been asking all along. The point has never been the trivial point of putting merely vexing hypothetical questions. That question is, rather, why would Americans who watched the grim events two summers ago in Tiananmen Square not want their First Amendment to apply? Who, really, now wants to rise up and condemn what the Court did in these cases? And who among the sponsors of the proposed amendment can say whether this is what the amendment would or would not do?

\section{Concluding Thoughts on the Proposed Amendment: What Do We Value in the United States?}

These last several observations bring us full circle. The object of the proposed 27 th Amendment was avowedly to protect the flag as a symbol of national unity. Virtually all agree that this was its main point. But it must be obvious that neither this nor any other 
amendment can advance that aspiration effectively, because unity is in the heart and in the mind of what people feel and clearly not in the model of a totalitarian law consecrating state symbols including our own. The fact is that in all the debates on the redrafted Federal statute and the proposed constitutional amendment, no one ever once gave a good reason why we should, as a people, desire to strip citizens of such right as they may otherwise have under the First Amendment, to try to reverse the Supreme Court in Texas v. Johnson. When we consider the protection Gregory Johnson received in the Supreme Court of the United States during the same summer we watched the "protection" of the students in Tiananmen Square in China, which example did we respond to? And how now do we want ourselves to be known?

In his first inaugural address as President of the United States, Thomas Jefferson-who had much to do with our First Amendment-spoke feelingly on the subject of patriotism, the subject that animates this proposed amendment. Jefferson spoke soberly on that occasion of those then seeking to dissolve the Union itself. "Let them stand undisturbed as monuments of the safety with which error of opinion may be tolerated when reason is left free to combat it," Jefferson declared. In most of the world, there are no real monuments of safety for dissent. Here at home, in Texas v. Johnson, however, our own Supreme Court reminded us that there is. The real monument of safety for dissent in the United States abides in the First Amendment in our Bill of Rights. We should take care to leave that amendment alone. In an odd way, moreover, we are unified in the freedom the First Amendment provides us. It is a freedom too little of this world is able to share.

\section{Notes}

I. Texas v. Johnson, 491 U.S.

109 S.Ct. 2533 (1989). The breakdown of votes on the Supreme Court confounded many Court watchers when the decision came down. Justices Kennedy and Scalia, Reagan appointees who had been regarded disparagingly by a number of observers at the time of their ascension to the Court, were crucial in providing the majority of five votes (including Brennan, Marshall, and Blackmun). Justice Stevens, the more warmly regarded appointee by President Ford, on the other hand, joined the dissent (including White, Rehnquist, and O'Connor).

2. The President's proposal followed not long after his successful presidential campaign against Michael Dukakis in 1988. In the course of that campaign, Mr. Bush repeatedly faulted Mr. Dukakis for his failure, as Governor of Massachusetts, to have signed a mandatory pledge of allegiance act applicable to all public school teachers - an act the Massachusetts Supreme Court had formally advised Dukakis could not constitutionally be enforced. [See the opinion of the Justices, 372 Mass. 874 (1977). I Without doubt, in promptly proposing the amendment following the Court's decision in Texas v. Johnson, Mr. Bush had again taken the initiative on a highly charged issue where the Democrats appeared most vulnerable, i.e., the issue of patriotism and love of country.

3. United States v. Eichman, 58 U.S.L.Wk. 2538 (D.C. Dis. Ct. March 5, 1990); United States v. Haggerty, 58 U.S.L.Wk. 2498 (Dis. W. Wash. 1990).

4. United States v. Eichman et al., No. 890-1438, June 11, 1990, 110 S.Ct. 2404 (affirming lower court, five to four). (The division within the Supreme Court was unchanged from the division in Texas v. Johnson itself.) The original act of Congress, 18 U.S.C. Section 700 (1968), provided that the offense was committed by "cast[ing] contempt upon any flag of the United States by publicly mutilating, defacing, defiling, burning, or trampling upon it." The new act, 18 U.S.C. Section 700 (Supp. 1990), made it nominally a matter of indifference whether one was or was not "casting contempt" on the flag, and whether one was or was not acting in public, i.e., it eliminated such language so that proof of purpose would no longer be of statutory consequence. Rather, the Federal crime was complete insofar as one "knowingly mutilates, defaces, physically defiles, burns, maintains on the floor or ground, or tramples upon any flag of the United States." In theory, therefore, the offense would be punishable wherever it occurred and without reference to the circumstances (if one "mutilated" a flag while alone in one's bedroom, or maintained a flag on the floor of one's locked attic, the statute would apply). 
5. Compare the wording of the Eleventh Amendment which is in this form as an amendment. The Eleventh Amendment was proposed and ratified in reaction to a particular Supreme Court decision (Chisholm v. Georgia, 2 Dall. 419 (1793). The Eleventh Amendment is reflexive-i.e., it expressly refers to language found in the Constitution in Article III of the Constitution (namely, "the judicial power of the United States") and provides expressly how that language shall not be construed - that it "shall not be construed to extend to" a case brought against a state by a citizen of another state. In contrast, the proposed 27th Amendment is unlike the Eleventh Amendment; i.e., it does not purport to say how the First or Fourteenth Amendments shall be construed or interpreted to apply to such acts of Congress as may forbid acts of physical desecration of the flag of the United States.

The proposed amendment is also unlike the Sixteenth Amendment, an amendment likewise proposed in reaction to a particular decision by the Supreme Court [Pollock v. Farmers' Loan \& Trust Co., 157 U.S. 429 (1895)]. The Sixteenth Amendment expressly authorizes income taxes to be levied by Congress "without apportionment." It thus makes clear that to whatever extent such taxes might previously have been valid only if apportioned by population according to the Supreme Court's interpretation and application of the Constitution's express apportionment requirement found in Article I, Section 9, Clause 4, income taxes would not hereafter be subject to judicial review on grounds of failing to conform to the apportionment clause.

6. The decision in Texas v. Johnson is at $109 \mathrm{~S} . \mathrm{Ct} .2533$ (1989). The State Court of Appeals decision, affirmed in the Supreme Court, is Johnson v. State, 755 S.W.2d 92 (Tex. Cr. App. 1988).

7. Johnson v. State, 755 S.W.2d 92, 97 (Tex. Cr. App. 1988). (Emphasis added.)

8. E.g., where the flag were government owned and the statute forbade defacing it either as government property or (in a suitable instance) as the property of another person, Johnson's demonstrative conduct would not be protected by the First Amendment from prosecution for the destruction of that property. (Interestingly in the actual case, the flag was a flag Johnson seized from government premises - but the prosecution wasn't brought for his act of arson or his act of theft but for his act of expressing contempt as such.)

9. Article I, Section 8, Clause 3.

10. Id. Clause 7.

11. E.g., an act of Congress may be fully constitutional as an affirmative exercise of Congress's express "power to regulate commerce among the several states," but, if the "commerce" is commerce in books (for instance) and if the regulation is one that seeks to restrict their free circulation, it may be invalid on pure First Amendment grounds. In turn, the power to establish post offices and post roads is separate from the power vested in Congress to regulate commerce among the several states; but every act providing for the treatment of the mail as such is also subject to full First Amendment review. [Indeed, the first decision of the Supreme Court to invalidate an express act of Congress on First Amendment grounds involved an act regulating the use of the mails, Lamont v. Postmaster General, 381 U.S. 301 (1965).] The express power granted to Congress to provide for post offices and post roads contains no provision excluding any exercise of that power from First Amendment review, of course; and again, neither does the proposed 27th Amendment contain any such exempting provision or clause.

12. E.g., an act making it a state or Federal offense for any person "physically to desecrate the flag of the United States. . .."

13. E.g., an arrest and prosecution of one who tears in half his own flag to demonstrate, in a public way across the street from the White House, his view that the government is acting wrongly in assisting the suppression of land reform movements in El Salvador or somewhere else. See also the numerous actual kinds of cases presented infra, in this review.

14. See, e.g., Halter v. Nebraska, 205 U.S. 34 (1907).

15. See, e.g., Spence v. Washington, 418 U.S. 405 (1974).

16. Cf. Street v. New York, 394 U.S. 576 (1969). For other significant Supreme Court cases on flag use and First Amendment protected dissent, see, e.g., Smith v. Goguen, 415 U.S. 566 (1974); Radich v. New York, 401 U.S. 531. aff' g, 26 N.Y.2d 114 (1970), on habeas corpus in U.S. ex rel. Radich v. Criminal Court, 459 F.2d 754 (2d Cir. 1972), cert. den. 409 U.S. 115 (1973); Bd. of Educ. v. Barnette, 319 U.S. 624 (1943); Stromberg v. California, 283 U.S. 359 (1931).

17. By stipulation, flag uses not covered by this amendment would remain fully subject to First Amendment protection in circumstances where that protection would otherwise be deemed mandated by the Supreme Court, although flag uses covered by this amendment would be stripped of such First Amendment protection. 
18. There was express testimony on behalf of the Department of Justice that the amendment would authorize legislation reaching this kind of act, so the matter is not some lawyer's contrived case. [See Hearings Before the Subcommittee on Civil and Constitutional Rights, House Judiciary Committee, 101 Cong. Ist Sess. 188-89 (Statement of Wm. Barr, Office of Legal Counsel), July $13,18,19,20,1989$.

19. The case [Spence v. Washington, 418 U.S. $405(1974)]$ is briefly noted at note 15 supra. The Supreme Court applied the First Amendment and reversed a criminal conviction on very similar facts.

20. But surely some will regard this as an act of "physical" disfigurement - that the tape is temporary or removable will surely not be of any point. (In Spence, Justice Rehnquist noted to sustain the criminal conviction, though the tape was removable without damage to the fabric of the flag.)

21. This case is modeled on an actual case it closely resembles, see Radich $v$. New York, 401 U.S. 531 (1971), aff g, 26 N.Y. 2d II4 (1970), on habeas corpus in U.S. ex rel. Radich v. Criminal Ct., 459 F.2d 754 (2d Cir. 1972), cert. den. 409 U.S. 115 (1973).]

22. The case is but a slight variation of Street v. New York, 394 U.S. 576 (1969) (reversing a state criminal court flag burning conviction on First Amendment grounds). 